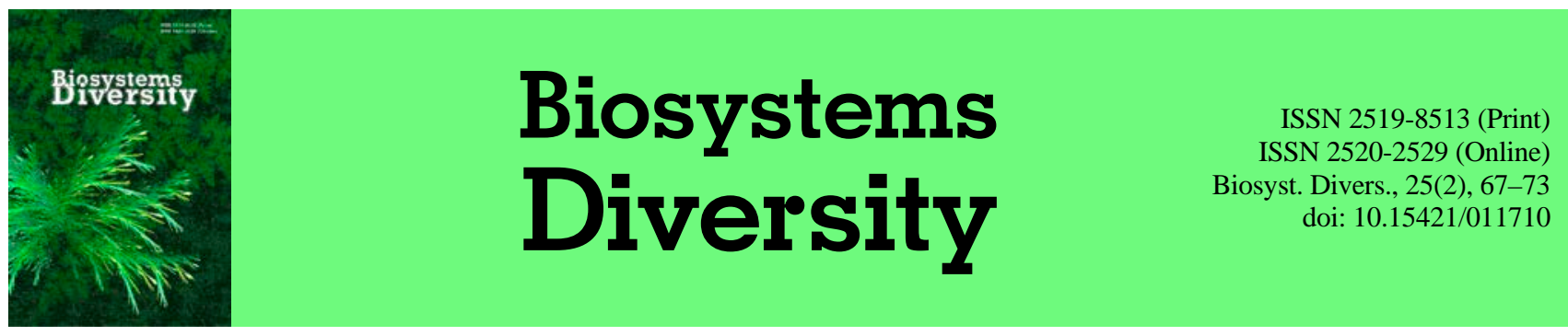

\title{
Spawning phenology of the white bream (Blicca bjoerkna) in "Dnieper-Orylskiy" Natural Reserve in relation to seasonal temperature dynamic
}

\author{
D. L. Bondarev*, O. V. Zhukov** \\ * “Dnipro-Orylskiy” Natural Reserve, Dnipro, Ukraine \\ **Oles Honchar Dnipro National University, Dnipro, Ukraine
}

Article info

Received 19.04.2017

Received in revised form 07.05.2017

Accepted 10.05.2017

"Dnipro-Orylskiy" Natura Reserve, Poletaev Str., 2, Dnipro, 49054, Ukraine. Tel.: +38-056-293-90-39. E-mail:dopz@ua.fm

Oles Honchar Dnipro National University,

Gagarin Ave., 72 ,

Dnipro, 49010, Ukraine.

Tel.: +38-056-760-84-38.

E-mail:

zhukov_dnepr@rambler.ru
Bondarev, D. L., \& Zhukov, O. V. (2017). Spawning phenology of the white bream (Blicca bjoerkna) in "DnieperOrylskiy" Natural Reserve in relation to seasonal temperature dynamic. Biosystems Diversity, 25(2), 67-73. doi:10.15421/011710

This paper examines the relationship between climatic conditions and the phenology of spawning of the white bream Blicca bjoerkna (Linnaeus, 1758) in natural habitats of the "Dnipro-Orilskiy" Nature Reserve. The characteristic of spawning distribution is symmetric, as the asymmetry coefficients do not significantly differ from zero. The distribution of the timing of spawning and its duration are also characterized by excesses, which do not significantly differ from zero alternatives. Analysis of meteorological data for the period of study allowed us to determine the trends in temperature variation, which correlate with the temperature of the water. Spawning events in any given year take place entirely within an upward temperature progression that can be accurately described by a linear equation in the form: $Y=b+a \cdot x$, where $Y$-ten-day average temperature; $x$ - the order of decades for I-VI months of the year, $a$ and $b$ - the parameters of the equation. The same equation can be used to describe downward movements in the temperature for decades during the VII-XII months of the year. Regression parameters and coefficients of determination have the following environmental sense. For the ascending temperature branch the regression coefficient $b$ will decrease in proportion to the increase in the contrast between winter and summer temperatures. Due to the fact that linear approximation is a certain generalization of the sinusoid natural course of temperature, it should be borne in mind that the highest summer temperatures are close to the change in direction in the course of temperature from increase to decrease. Therefore, the coefficient $b$ will largely depend on the minimum winter temperatures and should be interpreted as a marker of the coldness of the winter. This interpretation is all the more justified because we are concerned here with assessment of the impact on fish spawning, and the processes that precede spawning events clearly have importance for their explanation. Changes in the direction of the course of temperature which occur after spawning and have no value in explaining spawning. If we consider coefficient $b$ beyond the environmental context, then certainly this figure depends on the coldness of the winter and equally on the warmness of the summer. Similar considerations lead us to interpret the coefficient $b$ of a descending branch as a marker of the warmness of the summer. Comparison of the ascending temperature branch of the current year and the descending branch of the previous year gives the coefficient of correlation between these parameters of linear regression $\mathrm{r}=-0.10, \mathrm{P}=0.39$. This result confirms our assumption that the coefficient $b$ of a descending branch is a marker of the warmness of summer, because if it were a marker of the coldness of a winter, then the coefficient of correlation parameters for the temperature course that are common for this winter would be statistically significant. In addition, the absence of connections indicates that these coefficients provide independent and additional information about the weather conditions. Coefficient $a$ for the ascending branch characterizes the rate of warming during the spring, ie the rate of onset of summer, and for the descending branch - the rate of cooling in the fall, that is the speed of the onset of winter. The linear model reflects the general trend of warming in spring and cooling in autumn. In reality, the course of temperature change is by its nature a complex oscillatory process. Therefore the coefficient of determination of linear regression indicates the extent of correspondence of the real process to the linear model. Significant deviations from the general trend lead to a reduction in the coefficient of determination. These variations are the result of processes of sharp warming, alternating with periods of abrupt cooling. The more such events occur, the smaller the coefficient of determination. Thus, to describe the timing of spawning events we can examine the impact on them of such factors as regression model parameters for the current year for the ascending branch of temperature changes and parameters for the model of the previous year for the descending branch of temperature changes. As a result of our studies, we found that during the period 1997-2015 the typical course of temperature during the year is characterized by two branches: ascending and descending. The data obtained support the hypothesis that the onset of the various phases of spawning (the beginning of spawning, the end of spawning, spawning duration) is explained by temperature variation of the current year up to the spawning event and by temperature variation in the preceding year. The timing of the spawning of $B$. bjoerkna can be described at a statistically significant level by multidimensional factors reflecting the peculiarities of weather conditions and habitat type. The colder the previous summer and the winter of the current year and the fewer variables there are in the course of temperature, the later spawning occurs. The warmer the previous summer and the colder the winter of the current year, the later the spawning ends. Temperature variability in the course of temperature contributes to an earlier completion of spawning. There is a strong correlation between the beginning and the end of the spawning season so the impact of environmental factors at the beginning of spawning is also reflected in the timing of the end of spawning. The influence of conditions in the current year on the end of spawning is conditioned by the timing of the onset of spawning and the impact of weather conditions of the previous year on the end of spawning has independent significance.

Keywords: spawning; phenology; environmental factors; climate; regression analysis 


\title{
Фенологія нересту плоскирки (Blicca bjoerkna) у біотопах природного заповідника «Дніпровсько-Орільський» залежно від сезонної зміни температур
}

\author{
Д. Л. Бондарєв*, О. В. Жуков** \\ *Природний заповідник «Дніпровсько-Орільський», Дніпро, Украӥна \\ **Дніпровський національний університет імені Олеся Гончара, Дніпро, Украӥна
}

Установлено залежності фенології нересту плоскирки Blicca bjoerkna (Linnaeus, 1758) у біотопах природного заповідника «Дніпровсько-Орільський» від кліматичних умов. Протягом 1997-2015 рр. нерест плоскирки починався у діапазоні від 29 квітня до 23 травня (на 118-142-гу добу поточного року), а закінчувався в діапазоні від 20 травня до 12 червня (на 139-162-гу добу). Таким чином, нерест тривав 10-30 діб. Типовий хід температури протягом року характеризується наявністю двох гілок: висхідної та низхідної. Одержано дані, які підтверджують гіпотезу про те, що для пояснення часу настання етапів нересту значення має хід температури цього року до моменту настання події (початок нересту, кінець нересту, тривалість нересту) та хід температур минулого року. Терміни початку нересту плоскирки статистично вірогідно можуть бути описані за допомогою багатовимірних факторів, які відображають особливості метеорологічних умов та типів біотопу. Нерест настає тим пізніше, чим холодніші минуле літо та поточна зима, а також чим менш варіабельний хід температур. Кінець нересту настає тим пізніше, чим тепліше попереднє літо та чим холодніша зима. Варіабельність ходу температур сприяє ранньому завершенню нересту. Між термінами початку та кінця нересту існує сильний кореляційний зв'язок, тому вплив екологічних факторів на початок нересту віддзеркалюється також у термінах кінця нересту. Вплив умов поточного року на кінцевий термін нересту опосередковується терміном початку нересту, а вплив метеорологічних умов минулого року на термін закінчення нересту має самостійне значення.

Ключові слова: нерест; фенологія; екологічні фактори; клімат; регресійний аналіз

\section{Вступ}

У сучасних умовах державотворення України найефективніший шлях охорони різноманіття іiї живої природи - це функціонування мережі територій та об'єктів природно-заповідного фонду, і в першу чергу заповідників. Їх головна мета - збереження у природному стані типових або своєрідних для даної ландшафтної зони природних комплексів з усіма ії природними компонентами (Vyatchanina and Goncharenko, 1986, Het'man, 2005; Bulakhov et al., 2008). Саме з метою збереження унікального ландшафту долини середнього Дніпра та річки Оріль із комплексом характерної флори та фауни у 1990 р. створено природний заповідник «Дніпровсько-Орільський». Нині він єдиний у Дніпропетровський області. Заповідник репрезентує ландшафти та біорізноманіття долини Дніпра та його притоки p. Оріль. Загальна площа заповідника складає 3 766,2 га, а близько $30 \%$ цього припадає на акваторії, більшість із яких унікальні заплавні (Bondarev, 2015).

Заповідник розташований на верхній ділянці Дніпровського (Запорізького) водосховища, яка зазнала найбільшої антропогенної трансформації. Це зумовлює необхідність проведення комплексних іхтіологічних досліджень для визначення напрямків та глибини процесів, що відбуваються в популяціях риб його акваторії за дії сукупності антропогенних чинників (Bondarev et al., 1999; Bondarev, 2004, 2006, 2007). Дослідження іхтіофауни заповідника дозволяе не тільки визначити ії склад і характер розподілу у водоймах, а й установити направленість процесів, які відбуваються в екосистемі у цілому (Bulahov et al., 2003).

Розмноження - важливий екологічний процес, який забезпечує підтримання чисельності популяції та збереження виду. Пристосованість риб до умов розмноження та розвитку відображає не тільки основні екологічні умови водойм, а й вагомі риси інших стадій життєвого циклу виду (Kryizhanovskiy, 1949). Фенологічні показники відтворення риб характеризують біологічний стан популяції, а також можуть свідчити про наявність мікроеволюційних процесів і повною мірою відбивають процеси популяційного гомеостазу, їх характер і спрямованість (Nikolsky, 1974). Відповідно до загальної моделі репродуктивний цикл лососевих риб переважно регулюється тривалістю фотоперіоду, а коропових риб - температурою (Billard et al., 1978). Температура водного середовища - один із найважливіших факторів, який впливає на розвиток риб (Brett, 1979; Herzig and Winkler, 1986; Jobling, 2003). Температура також впливає на характеристики, пов'язані з репродукцією риб, a саме: визначення статті, динаміку гаметогенезу, якість гамет, плодючість, вікову та статеву зрілість, а також на тривалість репродуктивного сезону (Breton et al., 1980; Billard, 1986; Jafri, 1989; Sandström et al., 1995; Alavi and Cosson, 2005; Lahnsteiner and Mansour, 2012; Domagała et al., 2013). Підвищення температури внаслідок глобальних змін клімату стимулює ранні терміни нересту ляща, але нерест плотви відбувається у такі ж терміни, як і в період до змін клімату (Noges and Jarvet, 2005). У весняний період, який характеризується найсуттєвішими змінами на фоні глобального потепління клімату, відбувається нерест переважної більшості видів риб (Noges and Jarvet, 2005). Зміни фенології нересту можуть спричинити розсинхронізацію 3 розвитком планктону та каскадний ефект по трофічних ланцюгах, який може мати наслідки для всієї екосистеми (Blenckner, 2001; Edwards and Richardson, 2004). Дефіцит надійних тривалих відомостей про нерест риб - причина значно меншої кількості публікацій із фенології риб порівняно з фенологією птахів, метеликів і наземних рослин (McCarty, 2001; Noges and Jarvet, 2005).

Плоскирка Blicca bjoerkna (Linnaeus, 1758) - звичайний вид коропових риб у прісноводних водоймах майже всієї Європи та Азії (Berg, 1949; Tadajewska, 2000; Kottelat and Freyhof, 2007). Поширеність цього виду свідчить про важливу функціональну роль у підтриманні стійкості водних екосистем (Котроwski and Neja, 1999). Плоскирка - лімнофільний вид, зустрічається у великих озерах або у низовинах річок (Kottelat and Freyhof, 2007). Цей вид - еврифаг, живиться переважно безхребетними бентосу. Раціон плоскирки формують зоопланктон, молюски, хірономіди (Wielgosz and Tadajewska, 1988). Споживання плоскиркою зоопланктону сприяе зниженню рівня еутрофікації тих водойм, де вона мешкає (Beklioglu et al., 2011). Плоскирка - один із цільових видів, що обрані для біоманіпуляцій в евтрофованих озерах (Prejs et al., 1994).

Нерестовий сезон плоскирки продовжений у часі, а відкладання ікри відбувається декілька разів, звичайно двома або трьома порціями (Tadajewska, 2000). Деякі самиці мають недетермінований тип репродукції з однією або декількома порціями відкладення ікри (Kopiejewska and Kozłowski, 2007). Нерест може тривати 35-75 діб (Kopiejewska, 1996), або 21-52 діб (Spivak, 1987). Кількість порцій відкладення ікри залежить від чисельності риб в об'ємі води у водоймі на відповідній широті (Mann et al., 1984). Нерест звичайно відбувається у травні червні за температури понад $15^{\circ} \mathrm{C}$ (Kottelat and Freyhof, 2007).

Нерест плоскирки в різних регіонах Свропи відбувається майже у подібний період із початку травня до кінця червня, або навіть до початку липня - у Польщі (Domagała et al., 2015), 
Північній Pociї (Berg, 1949), Бельгії (Rinchard and Kestemont, 1996, 2003), Німеччині (Spratte and Hartmann, 1997; Molls, 1999). Найраніший нерест був зафіксований у Туреччині в квітні (Yılmaz et al., 2012, 2015; Okgerman et al., 2012). Нерест тільки протягом травня встановлений у водоймах Росії (Slastenenko, 1956) та Австрії (Hacker, 1979). Найтриваліший термін нересту в липні встановлений для Фінляндії (Koli et al., 1990) та Туреччини (Okgerman et al., 2012).

Мета цієї статті - охарактеризувати залежність фенології нересту плоскирки Blicca bjoerkna (Linnaeus, 1758) у біотопах природного заповідника «Дніпровсько-Орільський» від кліматичних умов.

\section{Матеріал і методи досліджень}

Як модельний об'єкт обрано плоскирку - широко розповсюджений, помірно численний вид у водоймах заповідника (Bondarev, 2015), який можна віднести до категорії фонових видів риб. Матеріали, що склали основу роботи, були зібрані на акваторії заповідника в 1997-2015 pp. з урахуванням типології водойм. Відбирання проб проводили стандартним набором знарядь лову (ставні сітки з вічком від 30 до 90 мм) на різних ділянках водойм заповідника. Усі роботи, пов'язані 3 вилученням риб із природних водойм заповідника, проводили згідно 3 діючими нормативами та інструкціями за стандартними іхтіологічними методиками (Arsan et al., 2006; Chugunova, 1952; Pravdin, 1966).
Під час досліджень проведено повний або неповний біологічний аналіз риб. Визначали вид, розмір, вагу, стать, стадію зрілості статевих продуктів, відбирали проби на визначення віку та плодючості. Визначення стадії зрілості статевих продуктів фактично давало змогу відстежувати фенологічні дати початку нересту риб окремих видів. Всі дані заносили в спеціальний журнал. Додатково відстежували погодні явища, коливання рівня води та визначали температуру води.

Для отримання даних щодо характеристики нересту та його інтенсивності у риб проводили візуальні спостереження та планові об'їзди нерестових угідь і через кожні 20, 50, 100 м розглядали рослинність та відшукували ікру риб. Якщо ікра знайдена, місце іiї знаходження детально описували. Вказували назву водойми, глибину, температуру води, час дня, яка рослинність і чи багато ікри (Koblitskaya, 1963).

Обробку зібраного матеріалу здійснено на базі лабораторії біомоніторингу НДІ біології ДНУ імені Олеся Гончара. Аналіз отриманих даних і статистичну обробку матеріалу проведено за допомогою прикладного програмного пакета Statistica v. 6.0 (StatSoft Inc., USA).

\section{Результати}

Нерест плоскирки починався у діапазоні від 29 квітня до 23 травня (на 118-142-гу добу поточного року), а закінчувався у діапазоні від 20 травня до 12 червня (на 139-162-гу добу). Таким чином, нерест триває 10-30 діб (табл. 1).

\section{Таблиця 1}

Описові статистики термінів нересту В. bjoerkna в період 1997-2015 pp. (кількість діб від 1 січня кожного року)

\begin{tabular}{|c|c|c|c|c|c|c|c|}
\hline \multirow{2}{*}{$\begin{array}{l}\text { Характеристики } \\
\text { термінів нересту }\end{array}$} & \multirow{2}{*}{$\mathrm{x} \pm \mathrm{SE}$} & \multirow{2}{*}{ Min } & \multirow{2}{*}{ Max } & \multicolumn{2}{|c|}{ Довірчий інтервал } & \multirow{2}{*}{ Асиметрія, As \pm SE } & \multirow{2}{*}{ Ексцес, $\mathrm{Ex} \pm \mathrm{SE}$} \\
\hline & & & & $-95 \%$ & $+95 \%$ & & \\
\hline Початок & $130,6 \pm 0,55$ & 118 & 142 & 129,5 & 131,7 & $-0,03 \pm 0,28$ & $0,46 \pm 0,56$ \\
\hline Кінець & $150,9 \pm 0,67$ & 139 & 162 & 149,5 & 152,2 & $-0,05 \pm 0,28$ & $-0,86 \pm 0,56$ \\
\hline Тривалість & $20,3 \pm 0,56$ & 10 & 30 & 19,2 & 21,4 & $0,21 \pm 0,28$ & $-0,57 \pm 0,56$ \\
\hline
\end{tabular}

Розподіл характеристик нересту симетричний, оскільки коефіцієнти асиметрії значимо не відрізняються від нуля (рис. 1). Розподіли термінів початку нересту та його тривалості також характеризуються ексцесом, який значимо не відрізняється від нульової альтернативи. Від'ємний ексцес для розподілу термінів кінця нересту свідчить про тенденцію до його двовершинності. Модель суміші 3 двох гауссових розподілів досить добре описує спостереження (статистика Колмогорова - Смирнова $\mathrm{d}=0,08, \mathrm{P}=0,75)$. Параметри розподілу - середні 148,19 (коефіцієнт суміші 0,71) та 157,20 (коефіщієнт суміші 0,29).

Аналіз метеорологічних даних за період досліджень дозволив визначити тренди варіювання температури повітря, 3 якою безумовно корелює температура у водоймах. Типовий хід температури протягом року характеризується наявністю двох гілок: висхідної та низхідної (рис. 2).

Для пояснення часу настання етапів нересту значення може мати хід температури цього року до моменту настання події (початок нересту, кінець нересту, тривалість нересту) та, вірогідно, хід температур минулого року. Події нересту цього року відбуваються цілком протягом висхідної гілки ходу температур, яку досить точно можна описати за допомогою лінійного рівняння виду:

$$
Y=b+a * X,
$$

де $Y$ - середня декадна температура, $X$ - порядок декад протягом I-VI місяців року, $a$ та $b$ - параметри рівняння.

Аналогічне рівняння можна застосувати для низхідної гілки ходу температур для декад протягом VII-XII місяців року.

Параметри регресії та коефіцієнти детермінації мають такий екологічний зміст. Для висхідної гілки регресійний коефіцієнт $b$ тим менший, чим більший контраст температур взимку та влітку. Коефіцієнт $b$ більшою мірою буде залежати від мінімальних температур взимку і його слід інтерпретувати як маркер холодності зими. Така інтерпретація тим більше обгрунтована, бо мова йде про оцінку впливу на терміни нересту риб і процеси, які передують подіям нересту, мають важливість для їх пояснення.
Зміна напрямку ходу температур відбувається вже після нересту, тож значення не має.

Якщо розглядати коефіцієнт $а$ поза екологічним контекстом, то, безумовно, цей показник залежить як від холодності зими, так $\mathrm{i}$ від спекотності літа. Аналогічні міркування приводять нас до інтерпретації коефіцієнта $a$ низхідної гілки як маркера спекотності літа. Порівняння коефіцієнтів висхідної гілки поточного року та низхідної гілки попереднього дають коефіцієнт кореляції між цими параметрами $\mathrm{r}=-0,10, \mathrm{P}=0,39$. Такий результат підтвердьжує наше припущення про те, що коефіцієнт $a$ низхідної гілки маркер спекотності літа, тому що якби він був маркером холодності зими, то коефіцієнт кореляції параметрів гілок ходу температур, спільних для даної зими, був би статистично вірогідним. Крім того, відсутність кореляції свідчить про те, що ці коефіцієнти дають незалежну та додаткову інформацію про метеорологічні умови.

Коефіцієнт $а$ для висхідної гілки характеризує швидкість потепління протягом весни, тобто швидкість настання літа, а для низхідної - швидкість похолодання восени, тобто швидкість настання зими.

Лінійна модель відображає загальний тренд потепління навесні та похолодання восени. У реальності хід температур має характер складного коливального процесу. Тому коефіцієнт детермінації лінійної регресії вказує на ступінь відповідності реального процесу лінійній моделі. Значні відхилення від загального тренду викликають зниження коефіцієнта детермінації. Ці відхилення наслідок перебігу процесів різкого потепління, які чергуються 3 періодами різкого похолодання. Чим більше таких явищ, тим менший коефіцієнт детермінації.

Таким чином, для описання термінів настання подій нересту ми можемо дослідити характер впливу на них таких показників як параметри регресійної моделі поточного року для висхідної гілки ходу температур і параметри для моделі попереднього року для низхідної гілки ходу температур (табл. 1).

Параметри регресійних моделей ходу температур характеризуються значним рівнем кореляції, що робить їх мультиколіне- 
арними предикторами, що зумовлює невизначеність параметрів регресійної моделі на їх основі. Багатовимірний факторний аналіз дозволяє знизити розмірність простору ознак та перейти до ортогональних змінних - факторів (рис. 1).
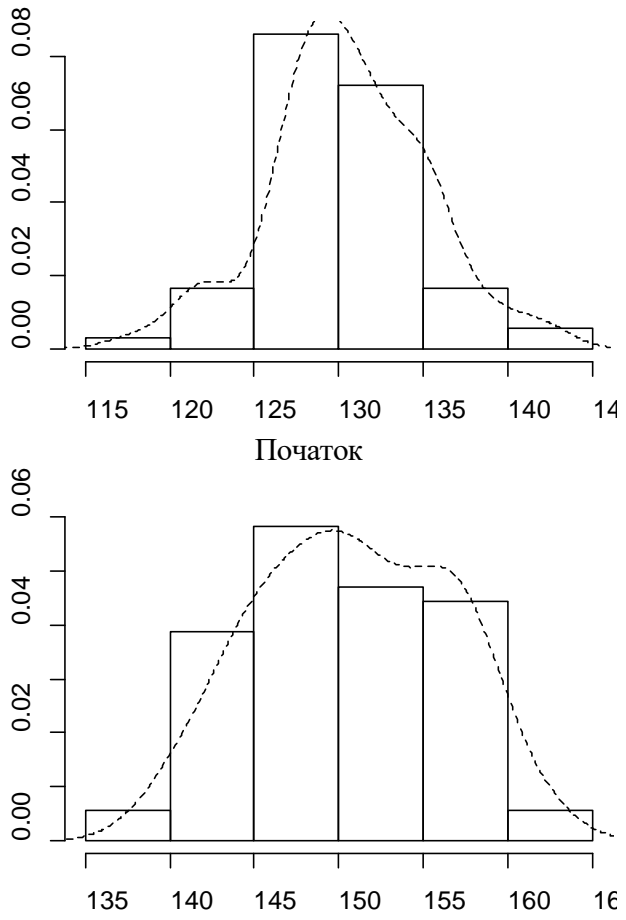

Кінець

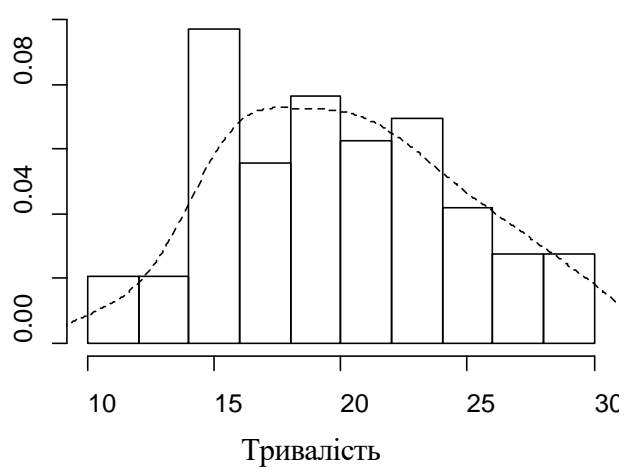

Рис. 1. Гістограми характеристик термінів нересту B. bjoerkna у період 1997-2015 рр.: вісь абсцис - кількість діб від 1 січня кожного року; вісь ординат - частота трапляння

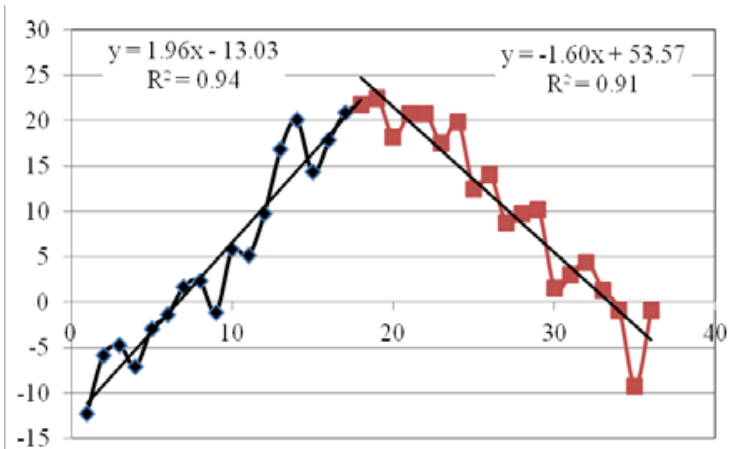

Рис. 2. Типовий хід температур протягом року (як приклад - дані 1997 р.): вісь абсцис - порядок декад із початку року, вісь ординат середня температура за декаду $\left({ }^{\circ} \mathrm{C}\right)$; ексепиментальні точки поєднані за допомогою сплайн-апроксимації; прямі лінії, що позначають тренд температур висхідної гілки ходу температур (зліва) та низхідної гілки ходу температур (справа), оцінені за допомогою лінійної апроксимації; наведено аналітичні рівняння відповідних трендів та коефіцієнти детермінації
Таблиця 1

Параметри регресійних моделей ходу температур протягом року

\begin{tabular}{|c|c|c|c|c|c|c|}
\hline \multirow{3}{*}{ Рік } & \multicolumn{6}{|c|}{ Параметри регресійної моделі } \\
\hline & \multicolumn{3}{|c|}{ для висхідної гілки } & \multicolumn{3}{|c|}{ для низхідної гілки } \\
\hline & $a_{1}$ & $b_{1}$ & $R_{1}^{2}$ & $a_{2}$ & $b_{2}$ & $R_{2}^{2}$ \\
\hline 1997 & 1,96 & $-13,03$ & 0,94 & $-1,57$ & 24,83 & 0,90 \\
\hline 1998 & 1,74 & $-8,91$ & 0,88 & $-1,94$ & 29,00 & 0,88 \\
\hline 1999 & 1,62 & $-6,93$ & 0,90 & $-1,84$ & 29,38 & 0,89 \\
\hline 2000 & 1,71 & $-9,24$ & 0,89 & $-1,57$ & 26,75 & 0,91 \\
\hline 2001 & 1,36 & $-5,51$ & 0,81 & $-2,18$ & 32,40 & 0,93 \\
\hline 2002 & 1,62 & $-6,87$ & 0,94 & $-2,16$ & 31,66 & 0,94 \\
\hline 2003 & 1,95 & $-12,99$ & 0,85 & $-1,54$ & 25,87 & 0,90 \\
\hline 2004 & 1,45 & $-6,84$ & 0,89 & $-1,46$ & 25,27 & 0,88 \\
\hline 2005 & 1,61 & $-8,32$ & 0,76 & $-1,67$ & 28,33 & 0,90 \\
\hline 2006 & 2,06 & $-14,29$ & 0,91 & $-1,58$ & 27,70 & 0,87 \\
\hline 2007 & 1,61 & $-6,41$ & 0,79 & $-1,88$ & 30,51 & 0,92 \\
\hline 2008 & 1,75 & $-9,23$ & 0,95 & $-1,76$ & 29,09 & 0,87 \\
\hline 2009 & 1,81 & $-9,76$ & 0,93 & $-1,71$ & 28,81 & 0,91 \\
\hline 2010 & 2,01 & $-11,88$ & 0,92 & $-1,77$ & 30,55 & 0,86 \\
\hline 2011 & 2,04 & $-13,50$ & 0,86 & $-1,72$ & 28,51 & 0,90 \\
\hline 2012 & 2,21 & $-13,54$ & 0,80 & $-1,92$ & 31,44 & 0,94 \\
\hline 2013 & 1,79 & $-7,92$ & 0,90 & $-1,65$ & 27,33 & 0,90 \\
\hline 2014 & 1,68 & $-7,98$ & 0,82 & $-1,76$ & 28,67 & 0,90 \\
\hline 2015 & 1,78 & $-9,62$ & 0,87 & $-1,77$ & 28,90 & 0,90 \\
\hline
\end{tabular}

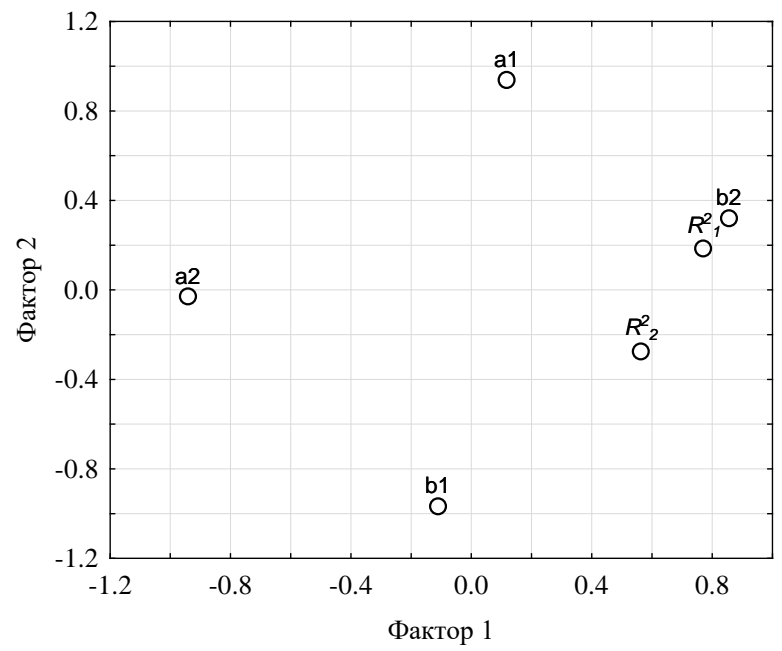

Рис. 3. Факторний аналіз параметрів регресійних моделей ходу температур протягом року (висхідна гілка) та протягом минулого року (низхідна гілка)

Перші два фактори характеризуються власними числами, що перевищують 1, які разом пояснюють 76,4\% дисперсії (47,7\% та 28,7\%, відповідно, фактори 1 та 2). Фактори протиставляють варіабельність параметрів моделі $a$ та $b$ для низхідної гілки (фактор 1) та висхідної гілки (фактор 2). Фактор 1 також чутливий до коефіціснтів детермінації. Таким чином, фактор 1 тим більший, чим спекотніше попереднє літо і чим більша швидкість зниження температури протягом літа - осені - зими. Також цей фактор чутливий до варіабельності ходу температур протягом попереднього та поточного року. Ця варіабельність, як правило, тим більша, чим вища температура літа попереднього року. Фактор 2 чутливий до перебігу температур поточного року. Він тим більший, чим холодніша зима та швидше відбувається прогрівання протягом весни. Терміни початку нересту плоскирки статистично вірогідно можуть бути описані за допомогою багатовимірних факторів, які відображають особливості метеорологічних умов та типів біотопу. Загалом, множинна регресійна модель здатна пояснити 47\% варіабельності термінів настання нересту плоскирки (табл. 1).

Нерест настає тим пізніше, чим більш холодне минуле літо та поточна зима, а також чим менш варіабельний хід температур. Слід зауважити, що особливості температурного режиму попереднього літа та поточної зими представлені ортогональними факторами, а тому є незалежними. 
Таблиця 1

Регресійний аналіз залежності термінів нересту B. bjoerkna від ходу температури та типів біотопів

\begin{tabular}{|c|c|c|c|c|}
\hline \multirow{2}{*}{$\begin{array}{c}\text { Параметри } \\
\text { моделей ходу } \\
\text { температур }\end{array}$} & \multirow{2}{*}{$\begin{array}{c}\text { Стандартизовані } \\
\text { регресійні } \\
\text { коефіцієнти } \pm \\
\text { ст. помилка } \\
\text { Початок нересту }\end{array}$} & \multicolumn{2}{|c|}{ Довірчі інтервали } & \multirow[b]{2}{*}{ p-рівень } \\
\hline & & $R_{a}^{2}=0,47$ & $+95,00 \%$ & \\
\hline PC1 & $-0,21 \pm 0,09$ & $-0,39$ & $-0,04$ & 0,02 \\
\hline PC2 & $0,49 \pm 0,09$ & 0,32 & 0,67 & 0,00 \\
\hline Бітоп & - & - & - & 0,00 \\
\hline \multicolumn{5}{|c|}{ Кінець нересту, $R_{a}^{2}=0,71$} \\
\hline PC1 & $0,11 \pm 0,06$ & $-0,01$ & 0,24 & 0,08 \\
\hline PC2 & $0,23 \pm 0,06$ & 0,11 & 0,36 & 0,00 \\
\hline Біотоп & - & - & - & 0,00 \\
\hline \multicolumn{5}{|c|}{ Кінець нересту, $R_{a}^{2}=0,74$} \\
\hline PC1 & $0,17 \pm 0,06$ & 0,04 & 0,29 & 0,01 \\
\hline PC2 & $0,11 \pm 0,07$ & $-0,04$ & 0,26 & 0,15 \\
\hline Початок нересту & $0,25 \pm 0,09$ & 0,08 & 0,43 & 0,00 \\
\hline Біотоп & - & - & - & 0,00 \\
\hline \multicolumn{5}{|c|}{ Тривалість нересту, $R_{a}^{2}=0,39$} \\
\hline PC1 & $0,35 \pm 0,09$ & 0,16 & 0,53 & 0,00 \\
\hline PC2 & $-0,21 \pm 0,09$ & $-0,39$ & $-0,02$ & 0,03 \\
\hline Біотоп & - & - & - & 0,00 \\
\hline \multicolumn{5}{|c|}{ Тривалість нересту, $R_{a}^{2}=0,63$} \\
\hline PC1 & $0,20 \pm 0,08$ & 0,05 & 0,35 & 0,01 \\
\hline PC2 & $0,13 \pm 0,09$ & $-0,05$ & 0,31 & 0,15 \\
\hline Початок нересту & $-0,68 \pm 0,10$ & $-0,89$ & $-0,48$ & 0,00 \\
\hline Біотоп & - & - & - & 0,00 \\
\hline
\end{tabular}
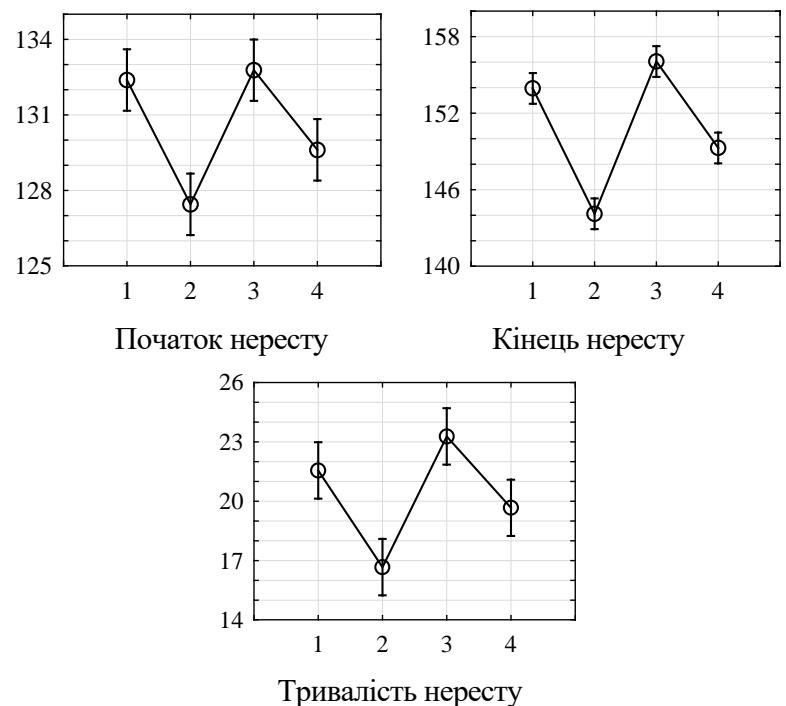

Рис. 4. Залежність термінів нересту B. bjoerkna від біотопу: кільця - середнє значення, вертикальні риски - 95\% довірчий інтервал; 1 - Миколаївський уступ, 2 - Обухівські плавні,

гирло р. Оріль, 3 - русло Дніпра, 4 - Таромський уступ

Регресійна модель здатна пояснити $71 \%$ варіабельності термінів настання кінця нересту. Кінець нересту настає тим пізніше, чим тепліше попереднє літо та чим холодніша зима. Варіабельність ходу температур сприяє ранньому завершенню нересту. Між термінами початку та кінця нересту - сильний кореляційний зв’язок $(\mathrm{r}=0,59, \mathrm{P}<0,001)$, тому вплив екологічних факторів на початок нересту віддзеркалюється також у термінах кінця нересту. Якщо у регресійну модель додати як предиктор інформацію про терміни початку нересту, їі характер дещо зміниться. Пояснювальна здатність такої моделі суттєво не змінюється, що свідчить про те, що додавання нового предиктора не несе суттєвої додаткової інформації. Але вплив фактора 2 перестає бути статистично вірогідним. Таким чином, вплив умов поточного року на кінцевий термін нересту опосередковується терміном початку нересту, а вплив метеорологічних умов минулого року на термін закінчення нересту має самостійне значення.

\section{Обговорення}

Терміни та місця нересту риб - пристосування до захисту від ворогів та забезпечення молоді їжею (Nikolsky, 1974). Репродуктивний цикл коропових риб переважно регулюється температурою (Billard et al., 1978). Результати наших досліджень свідчать про те, що в умовах заповідника плоскирка починає нереститися у водоймах заплави заповідника по досягненні температури води $14-15^{\circ} \mathrm{C}$. В інших частинах ареалу нерест також спостерігається за температури вищої $15^{\circ} \mathrm{C}$ (Kottelat and Freyhof, 2007). У більшості випадків нерест масовий та відбувається у прибережній зоні. Ікра відкладається на занурену водну рослинність або в очеретяних і рогозових заростях. Часто нерест можна фіксувати візуально. Зазвичай у водоймах заповідника плоскирка нереститься двічі на рік (перший нерест відбувається у травні - на початку червня, як виняток - останні дні квітня, а другий - у кінці червня на початку липня). В інших ділянках ареалу плоскирка відкладає ікру також двома або трьома порціями (Tadajewska, 2000).

Отримані під час дослідження дані дають змогу достовірно оцінювати лише перший нерест плоскирки. Найбільш ранній термін початку нересту під час проведення досліджень відмічено в 1997 році (29 квітня). Найпізніший початок нересту відмічено в 2006 році (17-23 травня).

Очевидно, що явище нересту визначається не тільки умовами у відповідний період, а й фізіологічним станом риб, який, у свою чергу, залежить від забезпеченості трофічними ресурсами та кліматичного режиму протягом усього періоду від кінця попереднього нересту. Для з'ясування залежності між термінами нересту та кліматичним режимом важливо кількісно виразити динаміку кліматичних умов. Динаміка кліматичних умов характеризується часовими рядами відповідних показників, у нашому випадку це температура повітря, яка у масштабі сезонних змін добре корелює 3 температурою води у водоймах.

Загальний багаторічний тренд зміни подекадних температур має чітко визначену синусоїдальну залежність. Але хід температур протягом періоду весняного збільшення або осіннього зменшення може бути досить точно апроксимований лінійною залежністю. Параметри лінійних моделей для кожного року - досить добрі маркери специфіки кліматичних умов, які застосовані як предиктори регресійних моделей для пояснення термінів настання та тривалості нересту. Ці параметри можуть бути змістовно інтерпретовані, що допомагає пояснити одержані моделі. Параметри моделей віддзеркалюють такі аспекти динаміки кліматичних умов як холодність зими або жаркість літа, темпи потепління навесні або темпи похолодання восени та ступінь нестабільності трендів потепління або похолодання. Ці параметри досить сильно скорельовані, тому перед застосуванням для регресійного аналізу вони були піддані багатовимірному аналізу головних компонент,

Цей підхід дозволив виокремити два ортогональні головні фактори. Перший фактор більшою мірою чутливий до варіації температурних умов минулого року, а другий - поточного. Регресійні моделі для термінів початку та кінця нересту специфічні, що свідчить про певну незалежність процесів, які впливають на ці явища. Подібність полягає у впливі перебігу кліматичних умов поточного року, а відмінність - у впливі перебігу минулого року. Інтенсивне настання весни спричиняе більш ранні терміни початку та кінця нересту. Але чим більш спекотне попереднє літо, тим раніше починається нерест та пізніше закінчується. У період iз нестійкими погодними умовами за варіабельністю температурних показників початок нересту реєструється у більш ранні строки. Його перебіг характеризується значною залежністю від природних умов. У разі значного похолодання він може перериватися, здебільшого кількість плідників на місцях нересту незначна. Крім того, термін його перебігу значно скорочується, а фенологічні дати його настання на різних біотопах наближені одна до одної. На відміну від цього, нерест, який відбувається в період «пізньої» весни, характеризується більш пізнім строком настання. Спостерігаються значні концентрації плідників на місцях нересту, його перебігу значно розтягується у часі. Фенологічні дати його 
початку та завершення в різних біотопах заповідника різняться. Біотопи характеризуються статистично вірогідними особливостями у термінах початку та тривалості нересту. Особливості нересту плоскирки у різних біотопах заповідника такі. У межах ділянок заплави (водойми Таромського уступу та Обухівської заплави) та гирла р. Оріль, які характеризуються слабкою проточністю та загальною мілководністю, нерест настає раніше, а його перебіг швидкоплинний. У межах інших ділянок акваторії заповідника, що характеризуються значними показниками проточності, а наявність мілководних ділянок, придатних для нересту, білыш обмежена, спостерігаються пізніші строки настання нересту плоскирки, його перебіг більш розтягнутий, а залежність від температурних факторів виражена більшою мірою, ніж на ділянках заплави. Очевидно, що варіювання температури повітря переломлюється через особливості водойм у специфічний температурний режим кожної окремої водойми. Безумовно, не тільки специфічність фізичних умов, а й біотичні особливості впливають на перебіг нерестового процесу у плоскирки.

Таким чином, аналіз наявних фенологічних даних і отриманих результатів (спостережень) дає змогу адекватно оцінювати екологічні особливості нересту плоскирки у водоймах заповідника. Виявлено залежність терміну настання нересту, його закінчення та загальної тривалості від існуючих природних умов, особливо впливу температурних факторів. Отримані результати у подальшому можуть мати значну цінність для загальної оцінки ефективності природного відтворення плоскирки в умовах наявних кліматичних змін. Це дасть змогу реально оцінювати загальний стан популяції плоскирки та прогнозувати рівень іiі природного поповнення не тільки в заповіднику, а й на прилеглих акваторіях Запорізького водосховища. Це дозволить розробляти та впровадьжувати ефективні екологічні заходи щодо ії охорони, відтворення та раціонального використання.

Також одержані дані свідчать про можливі заспокійливі прогнози щодо перспектив трансформації процесу репродукції риб у контексті можливого глобального потепління. Нерест плоскирки функція комплексу біоценотичних процесів, які меншою мірою керуються перебігом температур протягом року. Одержані результати свідчать про те, що популяційна система риб має пам'ять стосовно річної динаміки кліматичних умов. Ця пам’ять має характер накопичувача певних змін, при досягненні певного критичного стану система реагує у вигляді важливого явища у життєвому циклі риб - нересту. Глобальне потепління виражається у вигляді зсуву температурних кривих у бік збілышення. Кумулятивний характер реакції біологічних систем згладжує ці тренди. Існує вірогідність того, що зміни фенології нересту можуть спричинити десинхронізацію 3 розвитком планктону та каскадний ефект по трофічних ланцюгах, який може мати наслідки для всієї екосистеми (Blenckner, 2001; Edwards and Richardson, 2004). Але той факт, що терміни настання нересту - функція як абіотичної, так i біотичної складових, свідчить про те, що найвірогідніший сценарій - все ж таки синхронний характер змін внаслідок варіювання температурного режиму. Безумовно, це стосується певного рівня глобального потепління клімату.

\section{Висновки}

Протягом 1997-2015 років нерест плоскирки починався у діапазоні від 29 квітня до 23 травня (на 118-142-гу добу поточного року), а закінчувався у діапазоні від 20 травня до 12 червня (на 139-162-гу добу). Таким чином, нерест тривав 10-30 діб.

Типовий хід температур протягом року характеризується наявністю двох гілок: висхідної та низхідної. Одержано дані, які підтверджують гіпотезу про те, що для пояснення часу настання етапів нересту значення має хід температури цього року до моменту настання події (початок нересту, кінець нересту, тривалість нересту) та хід температур минулого року.

Терміни початку нересту плоскирки статистично вірогідно можуть бути описані за допомогою багатовимірних факторів, які відображають особливості метеорологічних умов і типів біотопу.
Нерест настає тим пізніше, чим холодніші минуле літо та поточна зима, а також чим менш варіабельний хід температур.

Кінець нересту настає тим пізніше, чим тепліше попереднє літо та чим холодніша зима. Варіабельність ходу температур сприяє ранньому завершенню нересту. Між термінами початку та кінця нересту існує сильний кореляційний зв’язок, тому вплив екологічних факторів на початок нересту віддзеркалюється також у термінах кінця нересту. Вплив умов поточного року на кінцевий термін нересту опосередковується початком нересту, а вплив метеорологічних умов минулого року на термін закінчення нересту має самостійне значення.

\section{References}

Alavi, S. M. H., \& Cosson, J. (2005). Sperm motility in fishes. I. Effects of temperature and pH: A review. Cell Biology International, 29(2), 101-110.

Arsan, O. M., Davydov, O. A., \& D’yachenko, T. M. (2006). Metody hidroekolohichnykh doslidzhen' poverkhnevykh vod [Methods of hydroecological researches of surface water]. Lohos, Kyiv (in Ukranian).

Beklioglu, M., Meerfhoff, M., Søndergaard, M., \& Jeppesen, E. (2011). Eutrophication and restoration of shallow lakes from a cold temperate to a warm mediterranean and a (sub) tropical climate. In: Ansari, A. A., Lanza, G. R., Gill, S. S., \& Rast, W. (Eds.), Eutrophication: Causes, consequences and control. Springer, New York, 91-108.

Berg, L. S. (1949). Ryby presnyh vod SSSR i sopredel'nyh stran [Fishes of fresh waters of the USSR and adjacent countries]. Part 2. Izdatel'stvo Akademii Nauk SSSR, Moscow - Leningrad (in Russian).

Billard, R. (1986). Spermatogenesis and spermatology of some teleost fish species. Reproduction Nutrition Développement, 26(4), 877-920.

Billard, R., Breton, B., Fostier, A., Jalabert, B., \& Weil, C. (1978). Endocrine control of the teleos reproductive cycle and its relation to external factors: Salmonid and cyprinid models. In: Gaillard, P. J., \& Boer, H. H. (Eds.), Comparative endocrinology. Elsevier / North Holland Biomedical Press, Amsterdam, 37-47.

Blenckner, T. (2001). Climate related impacts on a lake. From physics to biology. Acta Universitatis Upsaliensis. Comprehensive Summaries of Uppsala Dissertations from the Faculty of Science and Technology, 674, 37.

Bondarev, D. L., Hristov, O. A., \& Kochet, V. N. (2003). Ihtiofauna vodoemov Dneprovsko-Orelskogo zapovednika: Retrospektivnyiy analiz i sovremennoe sostoyanie [Ichtyofauna of the reservoirs of the Dnipr-Orel Reserve: Retrospective analysis and current status]. Visnyk of Dnipropetrovsk University. Biology, Ecology, 11(1), 13-20 (in Ukranian).

Bondaryev, D. L. (2004). Fauna ryb pryberezhnoyi zony Dniprovs'koOril's'koho zapovidnyka na suchasnomu etapi rozvytku ikhtiotsenozu [Current state of the fish fauna of the coastal zone of the Dnieper-Oril Reserve]. Visnyk of Dnipropetrovsk University. Biology, Ecology, 12(1), 712 (in Ukranian).

Bondaryev, D. L. (2006). Struktura nerestovoyi populyatsiyi plytki (Rutilus rutilus) vodoym Dniprovs'ko-Oril'skoho pryrodnoho zapovidnyka [The structure of the spawning populations of Rutilus rutilus of the DnieperOril Nature Reserve]. Visnyk of Dnipropetrovsk University. Biology, Ecology, 14(2), 20-25 (in Russian).

Bondaryev, D. L. (2007). Struktura nerestovoyi populyatsiyi lyashcha (Abramis brama) vodoym Dniprovs'ko-Oril'skoho pryrodnoho zapovidnyka [The structure of the spawning populations of bream (Abramis brama) of the Dnieper-Oril Nature Reserve]. Visnyk of Dnipropetrovsk University. Biology, Ecology, 15(1), 9-14 (in Russian).

Bondaryev, D. L. (2015). Ikhtiofauna pryrodnoho zapovidnyka "Dniprovs'koOril's'kyy" [The fish fauna of the Natural Reserve "Dnieper-Orylskiy»]. Naukovi Zapysky Ternopils'kogo Nacional'nogo Pedagogichnogo Universitetu, 3, 62-66 (in Ukranian).

Breton, B., Horoszewicz, L., Billard, R., \& Bieniarz, K. (1980). Temperature and reproduction in tench: Effect of a rise in the annual temperature regime on gonadotropin level, gametogenesis and spawning. I. The male. Reproduction Nutrition Développement, 20(1), 105-118.

Brett, J. R. (1979). Environmental factors and growth. In: Hoar, W. S., Randall, D. J., Brett, J. R. (Eds.) Fish physiology. Vol. 8. Bioenergetics and growth. Academic Press, NewYork, 599-675.

Bulakhov, V. L., Novits'kyy, R. O., Pakhomov, O. Y., \& Khrystov, O. O. (2008). Biolohichne riznomanittya Ukrayiny. Dnipropetrovs'ka oblast'. Kruhloroti (Cyclostomata). Ryby (Pisces) [Biological diversity in Ukraine. Dnipropetrovsk oblast. Cyclostomata (Cyclostomata). Fish (Pisces)]. Dnipropetrovsk University Press, Dnipropetrovsk (in Ukranian).

Bulakhov, V. L., Novyts'kyy, R. O., \& Khrystov, O. O. (2003). Ikhtiolohichni ta rybohospodars'ki doslidzhennya na Dniprovs'komu vodoskhovyshchi [Research on fish and fisheries management on the Dnipro Reservoir]. 
Visnyk of Dnipropetrovsk University. Biology, Ecology, 11(2), 7-18 (in Ukranian).

Chugunova, I. I. (1952). Metodika izucheniya vozrasta i rosta ryib [Methods of studying the age and growth of fish]. AN USSR, Moscow (in Russian).

Domagała, J., Dziewulska, K., Kirczuk, L., \& Pilecka-Rapacz, M. (2015). Sexual cycle of white bream, Blicca bjoerkna (Actinopterygii, Cypriniformes, Cyprinidae), from three sites of the lower Oder River (NW Poland) differing in temperature regimes. Acta Ichthyologica et Piscatoria, 45(3), 285-298.

Edwards, M., \& Richardson, A. J. (2004). Impact of climate change on marine pelagic phenology and trophic mismatch. Nature, 430, 881-884.

Hacker, R. (1979). Fishes and fishery in Neusiedlersee. In: Löffler, H. (ed.) Neusiedlersee: The limnology of a shallow lake in Central Europe. Dr. W. Junk Publishers, The Hague, Boston, London, 423-438.

Herzig, A., \& Winkler, H. (1986). The influence of temperature on the embryonic development of three cyprinid fishes, Abramis brama, Chalcalburnus chalcoides mentoand Vimba vimba. Journal of Fish Biology, 28(2), 171-181.

Het'man, V. (2005). Zapovidna sprava potrebuye upravlinnya [Reserve business management needs]. Naukovyy Svit, 1(8-9), 30 (in Ukranian).

Jafri, S. I. H. (1989). The effects of photoperiod and temperature manipulation on reproduction in the roach Rutilus rutilus (L.) (Teleostei). Pakistan Journal of Zoology, 21(4), 289-299.

Jobling, M. (2003). The thermal growth coefficient (TGC) model of fish growth: A cautionary note. Aquaculture Research, 34(7), 581-584.

Koblitskaya, A. F. (1963). Izuchenie nerestilisch presnovodnyih ryib [Study of the spawning of freshwater fish]. Pishevaya Promyshlenost, Moscow (in Russian).

Koli, L. (1990). Suomen kalat [Fishes of Finland]. Werner Söderström Osakeyhtiö, Helsinki (in Finnish).

Kompowski, A., \& Neja, Z. (1999). The Międzyodrze ichthyofauna as caught by various gear. Baltic Coastal Zone, 3, 103-112.

Kopiejewska, W. (1996). Germ line of white bream, Blicca bjoerkna (L.) females in Włocławek Reservoir. Acta Ichthyologica et Piscatoria, 26(2), 35-47.

Kopiejewska, W., \& Kozłowski, J. (2007). Development structure of ovaries in female white bream, Abramis bjoerknafrom Lake Kortowskie in North-Eastern Poland. Folia Zoologica, 56(1), 90-96.

Kottelat, M., \& Freyhof, J. (2007). Handbook of European freshwater fishes. Cornol (Switzerland) and Berlin (Germany). Published by the authors.

Kryizhanovskiy, S. G. (1949). Ekologo-morfologicheskie zakonomernosti razvitiya karovyih, vyunovyih i somovyih ryib [Ecological and morphological patterns of development Ciprinidae, Coritidae and Siluridae]. Trudy Instituta Morfologii Zhivotnyih AN SSSR, 1, 5-332 (in Russian).

Lahnsteiner, F., \& Mansour, N. (2012). The effect of temperature on sperm motility and enzymatic activity in brown trout Salmo trutta, burbot Lota lota and grayling Thymallus thymallus. Journal of Fish Biology, 81(1), 197-209.

Mann, R. H. K., Mills, C. A., \& Crisp, D. T. (1984). Geographical variation in the life-history tactics of some species of fresh-water fish. In: Potts, G. W., Wootton, R. J. (Eds.). Fish reproduction: Strategies and tactics. Academic Press, London, 171-186.

McCarty, J. (2001). Ecological consequences of recent climate change. Conservation Biology, 15, 320-331.

Molls, F. (1999). New insights into the migration and habitat use by bream and white bream in the floodplain of the River Rhine. Journal of Fish Biology, 55(6), 1187-1200.
Nikolskiy, G. V. (1974). Ekologiya ryib [Fish ecology]. Vyisshaya Shkola, Moscow (in Russian).

Noges, P., \& Jarvet, A. (2005). Climate driven changes in the spawning of roach (Rutilus rutilus (L.)) and bream (Abramis brama (L.)) in the Estonian part of the Narva River basin. Boreal Environment Research, $10(1), 45-55$.

Okgerman, H. C., Elp, M., \& Atasagun, S. (2012). The growth and reproduction of white bream (Blicca bjoerkna L. 1758) in an oligo-mesotrophic lake in northwest Anatolia (Sapanca, Turkey). Turkish Journal of Biology, 36(1), 125-134.

Pravdin, I. F. (1966). Rukovodstvo po izucheniyu ryib [Guide to the study of fish]. Pischevaya Promyshlennost', Moscow (in Russian).

Prejs, A., Martyniak, A., Boroń, S., Hliwa, P., \& Koperski, P. (1994). Food web manipulation in a small, eutrophic Lake Wirbel, Poland: Effect of stocking with juvenile pike on planktivorous fish. Hydrobiologia, 275(1), 65-70.

Rinchard, J., \& Kestemont, P. (1996). Comparative study of reproductive biology in single- and multispawner cyprinid fish. I. Morphological and histological features. Journal of Fish Biology, 49(5), 883-894.

Rinchard, J., \& Kestemont, P. (2003). Liver changes related to oocyte growth in roach, a single spawner fish, and in bleak and white bream, two multiple spawner fish. International Review of Hydrobiology, 88(1), 68-76.

Sandström, O., Neuman, E., \& Thoresson, G. (1995). Effect of temperature on life history variables in perch. Journal of Fish Biology, 47(4), 652-670.

Slastenenko, E. (1956). The fishes of the Black Sea Basin. The General Directorate of Meat and Fish Publications (in Turkish).

Spivak, E. G. (1987). Osobennosti razmnoženiâ gustery Blicca bjoerkna (L.) $\mathrm{v}$ zalivah Kahovskogo vodohranilisa [Reproduction of the white bream Blicca bjoerkna (L.) in Kahovsk Reservoir bays]. Voprosy Ihtiologii, 27(1), 101-105 (in Russian).

Spratte, S., \& Hartmann, U. (1997). Fischartenkataster: Suswasserfische und Neunaugen in Schleswig-Holstein. Ministerium für landliche Raume, Landwirtschaft, Ernahrung und Tourismus, Kiel.

Tadajewska, M. (2000). Krąp (Blicca bjoerkna L.) [White bream (Blicca bjoerkna L.)]. In: Brylińska, M. (Ed.). Ryby słodkowodne Polski. [Freshwater fish of Poland], PN, Warszawa, 249-257 (in Polish).

Vyatchanina, L. I., \& Goncharenko, N. I. (1986). Problemy ohrany okruzhayuschey sredyi i sohraneniya vidovogo raznoobraziya ryib Dneprovskih vodohranilisch [The problem of environmental protection and conservation of species diversity of fishes of the Dnipro river reservoirs]. Nauka, Moscow (in Russian).

Wielgosz, S., \& Tadajewska, M. (1988). Factors determining diet composition and food availability for bream Abramis brama (L.) and white bream Blicca bjoerkna (L.) in Włocławek Dam Reservoir. Acta Ichthyologica et Piscatoria, 18(1), 79-100.

Yılmaz, S., Yazıcıoğlu, O., Erbaşaran, M., Esen, S., Zengin, M., \& Polat, N. (2012). Length-weight relationship and relative condition factor of white bream, Blicca bjoerkna (L., 1758), from Lake Ladik, Turkey. Journal of the Black Sea/Mediterranean Environment, 18(3), 380-387.

Yılmaz, S., Yazıcıoğlu, O., Yazıcı, R., \& Polat, N. (2015). Age, growth and reproductive period of white bream, Blicca bjoerkna (L., 1758) in Lake Ladik, Turkey. Journal of Limnology and Freshwater Fisheries Research, 1(1), 9-18. 